\title{
Escolas comunitárias de imigrantes no Brasil: instâncias de coordenação e estruturas de apoio
}

\section{Lúcio Kreutz}

Universidade do Vale do Rio dos Sinos - UNISINOS

Programa de Pós-Graduação em Educação
Na história da educação brasileira registra-se uma iniciativa singular de escolas comunitárias de imigrantes. No entanto, o processo escolar étnico no Brasil não foi uma característica de todos os grupos de imigrantes. Os alemães, italianos, poloneses e japoneses, ao se estabelecerem em áreas rurais formando núcleos populacionais com características e estruturas marcantemente étnico-culturais, tiveram maior visibilidade enquanto imigrantes e promoveram as escolas elementares comunitárias.

Estas escolas tinham uma conotação fortemente étnica e, com exceção das escolas japonesas, também uma conotação fortemente confessional cristã. Além destas escolas comunitárias, houve um número significativo de escolas particulares mantidas por congregações religiosas, masculinas e femininas, geralmente em área urbana, mantendo especificidades étnicas do país de origem da mantenedora. Os imigrantes também tiveram escolas étnicas particulares laicas, em área urbana, mas em menor número que as anteriores. Diversas destas escolas particulares, tanto as de congregações religiosas como as laicas, tornaram-se conhecidas como centros de excelência no ensino de primeiro e segundo graus.
Para entender a dinâmica do processo escolar dos imigrantes é preciso estar atento não apenas para as diferenciações entre as etnias, mas também para a dinâmica de sua inserção no Brasil. Nos estados em que eles se concentraram mais em núcleos rurais, etnicamente homogêneos, promoveram escolas comunitárias a partir do apoio das respectivas lideranças religiosas, também de origem estrangeira. As "colônias" alemãs, italianas e polonesas, isoladas por longo período, empreenderam uma ampla estrutura comunitária de apoio ao processo escolar, religioso e sociocultural, à semelhança dos países de origem. Para favorecer a dinâmica comunitária nos núcleos de imigrantes, organizava-se um conjunto de 80 a 100 famílias, aproximadamente, com suas pequenas propriedades, em torno de um centro para a comunidade, com infraestrutura de artesanato, comércio e atendimento religioso-escolar. Era uma estrutura física indispensável para a rede de organizações socioculturais e religiosas a animar toda a dinâmica da vida comunitária. A imigração japonesa, que se iniciou no Brasil apenas a partir de 1908, também teve um processo de escolas comunitárias, mas com uma dinâmica de coordenação laica, a partir das Associações de Pais. 
O Brasil foi o país com maior número de escolas étnicas na América, embora tivesse um afluxo relativamente pequeno de imigrantes. Apenas 24\% dirigiramse à América do Sul, e o maior contingente optou pela Argentina. Esta recebeu 6.405.000 imigrantes entre 1856 e 1932, e o Brasil, em segundo lugar, registrou 4.903 .991 imigrantes entre 1819 e 1947. Enquanto isto a América Anglo-Saxônia recebeu 68\% da imigração européia (Carneiro, 1950).

No Brasil, o número mais expressivo de escolas étnicas foi dos imigrantes alemães, com 1.579 escolas em 1937, seguindo-se os italianos, com 396 escolas em 1913 (e 167 na década de trinta). Os imigrantes poloneses tiveram 349 escolas e os japoneses 178 (ou 260, ou 486?), ${ }^{1}$ também na década de trinta. Entre outros grupos de imigrantes ocorreram igualmente algumas iniciativas quanto a escolas étnicas, porém em menor número. Não houve proporção alguma entre o número de escolas étnicas e o total de imigrantes por etnia. Os alemães, primeiro grupo a imigrar a partir de 1824, formaram um total de 253.846 imigrantes até 1947. É um número pouco expressivo se comparado com o dos italianos, num total de 1.513.151 imigrantes, a partir de 1875. No mesmo período vieram para o Brasil 1.462.117 imigrantes portugueses, 598.802 espanhóis, 188.622 japoneses (a partir de 1908), 123.724 russos, 94.453 austríacos,

${ }^{1}$ Em diversos textos sobre escolas japonesas no Brasil apontase o número de 178 registradas oficialmente em 1932. Segundo Schaden (1980, p. 142), na véspera da Segunda Guerra Mundial estavam registradas no estado de São Paulo 260 escolas japonesas com 330 professores. Mas Ando (1976) afirma que depois disto ainda houve um grande aumento, chegando a 486 em 1939. Mesmo em relação às outras etnias, o número de escolas não é questão tranqüila. J. P. Coelho de Souza (1941, p. 72 s.), Secretário de Educação do Rio Grande do Sul no período da nacionalização do ensino, diz que no estado havia 2.418 escolas da imigração alemã, das quais fechou 241. O Interventor Federal no período, Cordeiro de Farias, afirma em relatório que foram fechadas 91 das 1.841 escolas teuto-brasileiras, em 1938. E nos levantamentos nominais das duas associações de professores teuto-brasileiros citam-se o nome e a localidade de 1.041 escolas (Rambo, 1996). Reconheço que há discrepâncias, e em alguns casos grandes. Trata-se de aproximações. Com o conjunto de pesquisas que vêm sendo realizadas nos últimos anos certamente se chegará a dados mais corretos.
79.509 sírio-libaneses, 50.010 poloneses e 349.354 de diversas nacionalidades (Carneiro, 1950). ${ }^{2}$ Quando, na década de 1930, havia 1.579 escolas da imigração alemã no Brasil, a Argentina tinha 204 escolas da mesma etnia, o Chile 45, o Paraguai 25 e o Uruguai 6 (Dalbey, 1969, p. 183).

A tradição escolar era bastante diferenciada entre as diversas etnias de imigrantes. A Secretaria da Agricultura de São Paulo, ao registrar os que entraram pelo Porto de Santos entre 1908 e 1932, constatou que o índice de alfabetização era de $91,1 \%$ entre os alemães, $89,9 \%$ entre os japoneses, $71,3 \%$ entre os italianos, 51 , $7 \%$ entre os portugueses e 46,3\% entre os espanhóis (Demartini, 1998, p. 2). Schaden (1980, p. 141), tomando um período histórico um pouco mais longo e falando não apenas dos que entraram pelo Porto de Santos, apresenta números diferentes. Diz que dos imigrantes que entraram no Brasil entre 1908 e 1941, 87,2\% dos alemães eram alfabetizados, sendo que entre os japoneses eram $72,9 \%$ e entre os espanhóis $28,4 \%$. Estudos indicam que também havia variações consideráveis no índice de alfabetização entre imigrantes de um mesmo grupo étnico, dependendo de sua região de proveniência. Enquanto os italianos que entraram pelo Porto de Santos tinham um índice de 71,36\% de alfabetizados, o censo municipal de 1906 registra que em Alfredo Chaves (RS), dentre os 22.707 habitantes, 16.110 eram analfabetos. Fato semelhante ocorria em outros municípios com imigração italiana, como Antônio Prado (RS), Criciúma e Nova Veneza (SC), entre outras localidades (De Boni, 1987, p. 219). Giron (1998) diz que, ao fazer o levantamento dos Mapas Estatísticos da Colônia de Caxias, verificou que $63 \%$ dos homens e $37 \%$ das mulheres eram alfabetizados. Wachowicz (1970, p. 145) também relata que entre imigrantes poloneses o índice de alfabetização variava bastante, sendo muito baixo entre os provenientes

\footnotetext{
${ }^{2}$ Costa, E. Viotti (1977); Bruit (1982); Schorer Petrone (1982)
} e Diegues Júnior (1960 e 1976), entre outros, também tratam da questão do número de imigrantes para o Brasil. Alertam que não se tem estatística exata a respeito e que os números devem ser tomados como aproximação. Carneiro diz que os dados levantados por ele talvez não contemplem o número total de imigrantes, mas que, em todo caso, não pecam por exagero. 
das regiões ocupadas por potências estrangeiras (Rússia e Prússia) que haviam dificultado a escolarização nestas regiões.

Os imigrantes pressionaram o Estado em favor de escolas públicas. Mas no período mais intenso da imigração, a partir de 1890, o Brasil tinha um sistema escolar altamente deficitário, com uma população de mais de $80 \%$ de analfabetos. Não tendo condições ou política prioritária para a oferta de escolas, o governo estimulou os imigrantes a abrirem escolas étnicas. $\mathrm{O}$ administrador de São Leopoldo, núcleo original dos imigrantes alemães, no Rio Grande do Sul, queixando-se ao Presidente da Província da deficiência de escolas públicas, relatou que havia apenas três destas em relação a 23 escolas da imigração alemã, das quais apenas uma ensinava em português. Por isto pedia um decreto obrigando o ensino da língua nacional nas escolas da imigração. Contra sua expectativa, o Presidente da Província permitiu o ensino em alemão também nas escolas públicas da região colonial (Carneiro, 1950; 1960, p. 88).

Na década de 1920 o número de escolas étnicas italianas, mais concentradas na área urbana, diminuiu sensivelmente no estado de São Paulo, então em rápido processo de industrialização e centro do debate sobre referenciais para a nacionalidade brasileira. As escolas japonesas ainda continuavam em expansão. Nos outros estados, as escolas dos imigrantes estavam mais concentradas em área rural, e seu número foi aumentando até os primeiros anos da década de trinta. A partir da Primeira Guerra Mundial, o governo já havia iniciado um processo de nacionalização preventiva, abrindo escolas públicas perto das étnicas, sem impedir, porém, o funcionamento destas. Começou a tratá-las com mais restrição a partir do final da década de vinte, em tendência crescentemente nacionalista. E em 1938/39, momento da nacionalização compulsória do ensino, estas escolas foram fechadas ou transformadas em escolas públicas por meio de uma seqüência de decretos de nacionalização. ${ }^{3}$

\footnotetext{
${ }^{3}$ A legislação federal concernente à nacionalização do ensino começou com o Decreto n ${ }^{\circ} 406$, de maio de 1938, dirigindo-se diretamente às escolas étnicas. Foi decretado que o material usado nestas escolas fosse em português, que os professores e diretores de escolas
}

Embora esteja retomando, de forma sucinta, vários dados já apresentados em outras publicações, ${ }^{4}$ julgo necessário fazê-lo para contextualizar o presente texto e também porque sugerem todo um leque de questões de pesquisa relacionadas com as escolas da imigração no Brasil. O significado deste processo escolar vem sendo objeto de investigação a partir dos anos oitenta e de forma mais intensa na última década. Estas investigações abordam predominantemente a experiência de uma determinada escola, de uma pequena região ou de um aspecto específico do processo escolar de uma etnia, como, por exemplo, a formação do professor, o livro didático, etc. Poucas são as pesquisas que tratam do processo escolar étnico em sentido mais amplo, e os estudos reali-

fossem brasileiros natos, que nenhum texto, revista ou jornal circulasse em língua estrangeira nos distritos rurais, e que o currículo escolar deveria ter instrução adequada em história e geografia do Brasil. Proibia ainda o ensino de língua estrangeira a menores de 14 anos e ordenava que se desse lugar de destaque à bandeira nacional em dias festivos. Em 10 de dezembro de 1939, o Presidente da República assinou outro Decreto, de $\mathrm{n}^{\circ} 1.006$, estabelecendo que o Ministro da Educação procedesse a uma censura em todos os livros usados na rede de ensino elementar e de $2^{\circ}$ Grau. Todavia, o decreto de nacionalização mais importante talvez tenha sido o de $\mathrm{n}^{\circ} 1.545$, de 25 de agosto de 1939. Instruíam-se os Secretários de Educação, nos estados, para construir e manter escolas em área de colonização estrangeira, para estimular o patriotismo por parte de estudantes, para fiscalizar o ensino de línguas estrangeiras e para intensificar o ensino de história e geografia do Brasil. Proibia-se expressamente que alguma escola fosse dirigida por estrangeiro e que se fizesse uso de língua estrangeira em assembléias e reuniões públicas. Ordenava-se ainda que a educação física nas escolas fosse colocada sob a direção de um oficial ou sargento das Forças Armadas indicado pelo comandante militar da região. Em 8 de março de 1940, o Decreto nº 2.072 criava a Organização da Juventude Brasileira, tornando-a obrigatória para todas as escolas. Jovens de 11 a 18 anos deveriam submeter-se à educação física como instrumento importante para uniformizar diferenças étnicas por meio de exercícios físicos em comum. Em 3 de setembro de 1941, o Decreto Federal n 3.580 proibia tanto a importação de livros-texto de língua estrangeira para o ensino elementar como sua impressão em território nacional (Dalbey, 1969, p. 199202). Além disso, os diversos estados com escolas de imigrantes ainda tiveram legislação complementar específica para encaminhar a nacionalização do ensino (Kreutz, 1994b, p. 45-46).

${ }^{4}$ Veja-se Kreutz (1994c; 2000a; 2000b). 
zados ainda têm tido pouca divulgação, o que dificulta estudos comparativos. ${ }^{5}$

Nos estudos que venho realizando, percebo de forma cada vez mais clara que as escolas comunitárias não se desenvolveram de forma isolada, cada uma restrita a seu núcleo rural. Ao contrário, não obstante serem assumidas pelas respectivas comunidades de imigrantes, elas estavam vinculadas a uma instância maior, na qual se promoviam a coordenação e a animação do processo escolar com todo um conjunto de estruturas de apoio, sempre em inter-relação com outras instâncias socioculturais das respectivas etnias. Assim, a formação do professor, a produção do material didático, a frequiência obrigatória à escola não eram tratadas como questões isoladas. Faziam parte de um todo maior.

Traversini (1998) sentiu-se desafiada para fazer um estudo de caso sobre a alfabetização em Poço das Antas, RS, ao tomar conhecimento de que este município, juntamente com outros dois municípios gaúchos e dois de São Paulo, tinham sido classificados com taxa de $100 \%$ de alfabetização, através de levantamento do Fundo das Nações Unidas para a Infância (UNICEF), no Censo de 1991. Ao trabalhar com as informações do UNICEF, a Folha de S. Paulo (24/03/96) constatou que dos $50 \mathrm{mu}-$ nicípios mais alfabetizados do Brasil, 33 eram do Rio Grande do Sul e que 29 destes, localizados nos vales do rio Caí, do rio Taquari e na Serra Gaúcha, formavam o polígono com o "Oscar da alfabetização". Esta região é predominantemente de descendentes de imigrantes. Traversini foi a Poço das Antas achando que encontraria os motivos deste sucesso no sistema educacional, certamente associado ao progresso industrial, comercial

\footnotetext{
5 Alguns passos iniciais estão sendo dados neste sentido. Demartini (1998 e 1989) compara as pesquisas que realizou com descendentes de imigrantes japoneses e portugueses, em São Paulo, procurando desvendar os significados atribuídos ao processo de escolarização destes grupos. Em Kreutz (2000a) apresento uma descrição das escolas da imigração, enfocando a política governamental que incentivou a imigração, permitiu/estimulou as escolas étnicas e gerou tensões entre Estado e grupos étnicos em relação à diferenciada concepção de nação/nacionalidade, culminando com a supressão destas escolas em 1938/9. E em Kreutz (2000b) comparo o processo escolar dos imigrantes alemães na Argentina, Brasil e Chile.
}

e à urbanização. Constatou que não. Teria havido, então, uma grande campanha de alfabetização? Inovações pedagógicas, renovação curricular? Ou formação especial de professores? Observou que não. O que pôde perceber foi que a escola estava bem enraizada no contexto cultural da população, que ser alfabetizado era considerado como algo natural. O ser alfabetizado estava sendo entendido como algo constitutivo da identidade cultural desta população e não como resultado de uma iniciativa específica. A pesquisadora observa que seu estudo trata de um município específico e que não pretende generalizar conclusões.

Nas pesquisas sobre o processo escolar dos imigrantes alemães no Brasil, percebi que a concepção de que todos deveriam ser escolarizados é uma constante em sua literatura. Aplicavam sanções religiosas severas para quem não fosse à escola. E em entrevistas realizadas em 1982 com ex-professores, que haviam trabalhado na escola teuto-brasileira ainda na década de 1930, os mesmos foram unânimes no depoimento de que já naquele período haviam sido poucos os casos de analfabetismo em comunidades rurais teuto-brasileiras. Estas observações levaram-me a perceber o quanto algumas etnias de imigrantes vincularam o processo escolar com a dinâmica mais ampla de seu processo comunitário e o quanto toda esta estrutura vinha sendo coordenada explicitamente para esta vinculação.

Trata-se de um tema pouco pesquisado. Por isto, neste texto, pretendo contribuir para o estudo da questão, mesmo que seja de forma inicial. A partir das fontes e estudos aos quais tive acesso até o momento, procuro fazer um passo inicial na explicitação. Neste texto pretendo contribuir para a explicitação das instâncias de coordenação e de toda uma estrutura de apoio a este processo escolar comunitário, com diferenciações entre as etnias, restringindo-me ao período histórico do início da imigração até 1939, quando toda esta experiência escolar terminou através da nacionalização do ensino. Limito-me às escolas comunitárias étnicas em área rural. As escolas particulares laicas e de congregações religiosas em área urbana não serão objeto deste estudo. Também não tratarei das escolas de imigrantes italianos e alemães em São Paulo. Procurados por uma política de imigração que visava obter mão-de-obra para a indústria e 
para as lavouras de café, sem acesso imediato à propriedade rural, formaram poucos núcleos etnicamente homogêneos, e suas escolas tiveram uma dinâmica de coordenação diferente daquela de outros estados, especialmente os três sulinos. Os imigrantes japoneses com escolas em área rural apresentavam certas semelhanças com as escolas comunitárias de outras etnias, diferenciando-se em relação às instâncias de coordenação e animação deste processo. Sua inclusão neste estudo permite visualizar melhor o quanto as iniciativas relativas à escola, embora tenham certos traços comuns aos diversos grupos de imigrantes, também mantêm especificidades das diversas tradições culturais.

\section{Processo escolar sob a liderança dasigrejas}

Nas regiões de proveniência da maior parte dos imigrantes alemães, poloneses e italianos, predominava o motivo religioso na educação até fins do século XVIII. O objetivo era formar bons cristãos. Além do ensino do ler, escrever e contar, considerava-se a catequese como prioritária. A partir do gradativo avanço do Estado na organização do processo escolar laico, as igrejas reagiram, reivindicando seu direito divino nesta matéria, desenvolvendo intensa atividade em favor da escola confessional. Incentivaram toda uma estrutura de apoio para reavivar a tradição do professor comunitário e paroquial. Neste sentido as igrejas católicas e luteranas fundaram Escolas Normais para a formação de professores comprometidos com a dimensão religiosa, concebendo-os como agentes importantes de ação pastoral (Joerg, 1960). O professor ideal seria aquele com raízes no povo, vivendo com o povo, compromissado com os fundamentos da religião, imbuído de santo respeito por sua missão, entendida como vocação e sacerdócio. Segundo Overberg (1754-1826) e Kellner (1811-1892), fortes lideranças neste sentido, uma escola sem vinculação direta com o religioso não teria o centro vital, a alma, a partir do qual pudesse desenvolver-se (LZ, 1927, março, p. 1-3).

Os imigrantes provieram desta efervescência de iniciativas em relação à escola. Mas vieram também marcados pela tensão entre Estado e Igreja quanto à competência no campo educacional. Assim, por exemplo, enquanto na Prússia se difundia rapidamente a escola pública, mantinha-se ainda o predomínio das igrejas na organização das mesmas em grande parte das comunidades rurais das regiões de pequenas propriedades rurais, com milenar tradição cristã. Marx (1981, p. 133) salienta que aí se formaram as comunidades rurais compostas de um número maior ou menor de famílias de proprietários com acentuada integração religiosa, social e cultural. Entende que esta é uma herança direta da "comunidade germânica" antiga que, em diversos lugares, sobreviveu a todas as vicissitudes da Idade Média, constituindo-se no "único fortim da liberdade popular e da vida popular".

A tensão entre o Estado laico, inspirado nas perspectivas da Ilustração, e as Igrejas cristãs, sob o Romantismo Conservador, foi muito forte nos países de origem dos imigrantes europeus, que não aceitaram pacificamente a expansão do ideário da Revolução sob o signo do Liberalismo. Consideravam-no uma ameaça para a tradicional ordem política e religiosa. Por isto, nestes países ensaiou-se uma resistência ao avanço do ideário liberal, conjugando-se esforços num movimento em favor da restauração da antiga ordem política e social, inspirando-se no Romantismo, na sua corrente conservadora. Sonhava-se com a unidade perdida e se clamava por uma comunidade ideal. Propugnava-se pelos valores "orgânicos" em oposição aos "mecânicos" da crescente industrialização, postulando a prioridade dos valores religiosos na perspectiva tradicional. Estas idéias tiveram especial receptividade na Alemanha e Itália, onde crescia o movimento em favor da restauração política e religiosa, enquanto a Inglaterra e a França formavam a principal força na Europa em favor do Liberalismo (Romano, 1981).

As primeiras décadas de imigração revelam iniciativas relacionadas com o processo escolar étnico, que foram encaminhadas de forma isolada pelas diversas comunidades de imigrantes. A partir de 1870, quando a influência do liberalismo se fazia sentir crescentemente também entre os imigrantes, através dos "Brummer", ${ }^{6}$ a

${ }^{6}$ Os Brummer eram combatentes contratados pelo Império para lutar na Guerra contra Rosas, da Argentina, em 1852. Tratava-se de alemães que haviam participado estreitamente das revoluções libe- 
Igreja Católica e a Luterana começaram a fazer uma frente de oposição ao avanço deste ideário. Embora católicos e luteranos tivessem um alinhamento diferenciado com o Movimento da Restauração no Rio Grande do Sul, as lideranças destas igrejas junto aos imigrantes declararam, em 1872, que, apesar das diferenças históricas, estavam conjugando esforços numa frente de oposição ao avanço do liberalismo ateu (Kreutz, 1991, p. 61s). A partir de então as duas confissões religiosas centraram suas atividades junto aos imigrantes principalmente em torno da difusão da imprensa, do associativismo e da escola. Algumas grandes iniciativas foram comuns entre as duas igrejas. No entanto, a maior parte da ampla estrutura de apoio aos imigrantes, na qual a escola recebia uma atenção especial, tinha caráter confessional. Opondo-se ao movimento de laicização do ensino e entendendo a expansão da rede pública de escolas como perda de terreno, as duas confissões religiosas investiram numa ampla estrutura de coordenação e incentivo às escolas comunitárias junto aos imigrantes. E assim, a escola entre imigrantes começou a ser vinculada a projetos específicos da Igreja Católica e da Evangélica, adquirindo cada vez mais uma conotação confessional. Iniciou-se o movimento para a formação das associações de professores que servissem de elemento catalisador e que se tornassem um canal de intervinculação entre igreja e escola. A maior parte das escolas dos imigrantes alemães, poloneses e, em parte, dos italianos, foram criadas comunitariamente e, ao mesmo, tempo vinculadas à coordenação das igrejas. Eram escolas comunitárias e confessionais.

rais sufocadas na Europa a partir de 1848. Após a luta contra Rosas, em torno de 1.800 deles se estabeleceram no Rio Grande do Sul. Conquistaram rápida ascendência sobre os imigrantes, pois tinham formação acadêmica superior à deles e participação em movimentos sociais mais marcantes. Segundo Schmid (1949, p. 23), eles foram um "fermento" entre os imigrantes, estimulando o desenvolvimento material e cultural. Trabalhavam em favor da nacionalização dos imigrantes, de sua participação política, da difusão da imprensa e da promoção do processo escolar. Em 1870, mais da metade dos professores da imigração alemã eram Brummer. O apelido "Brummer" foilhes atribuído porque eram questionadores, os que faziam "zunido". Sobre aspectos específicos de sua influência entre os imigrantes e a reação das igrejas, ver Kreutz, 1991, p. 59s.
Todas as iniciativas quanto à produção de material didático, organização curricular, escolha e manutenção do professor não foram tomadas como uma questão isolada, independente, restrita aos interesses de cada núcleo rural em si. Ao contrário, a partir do final do século XIX, toda a questão escolar e curricular foi planejada, incentivada e reestruturada como um assunto de interesse comum e que teria também coordenadas comuns, com diferenciações menores em nível local. As igrejas católica e evangélica assumiram a questão escolar como seu principal ponto de apoio para a ação continuada nos núcleos rurais. Em contrapartida, as sanções também eram religiosas para quem não se comprometesse com a escolarização dos filhos e a manutenção da escola e do professor. ${ }^{7}$

Para ter uma adequada compreensão das iniciativas dos imigrantes em relação à escola, é necessário que se tenha noção da estrutura física sem a qual não teria sido possível toda esta dinâmica de interações comunitárias. Mas também é necessário vinculá-las à tradição cultural dos imigrantes, ao momento histórico de oposição entre Igreja e Estado, motivando a dinamização de uma forte estrutura comunitária, com ampla rede de associações, numa perspectiva predominantemente religiosa.

\section{Dinâmica do processo escolar comunitário entreimigrantes}

Os imigrantes que empreenderam iniciativas comunitárias para o processo escolar entendiam, logicamente, que a escola era importante para eles. Tanto assim que esta foi a primeira iniciativa comunitária para várias etnias. No entanto, essas etnias tinham uma história cultural diferente, inclusive em relação ao processo escolar. Ciente desta diversidade, embora ainda sem uma profunda compreensão de como caracterizála, dou um passo inicial neste sentido. Por isto apre-

${ }^{7}$ Os aspectos apontados de forma bem sucinta encontram-se mais desenvolvidos em Dreher (1984 e 1986), De Boni (1980), Kreutz (1991 e 1994), Rambo (1994 e 1996), Hoppen (1986), Wachowicz (1970) e Gardolinski (1977), que desenvolvem a vinculação das igrejas católica e luterana com esta coordenação de estruturas comunitárias entre os imigrantes no Brasil. 
sento esquematicamente alguns elementos que sinalizam especificidades de cada etnia na representação e ativação da dinâmica de seu processo escolar comunitário. Em relação aos imigrantes alemães ainda é preciso distinguir entre os de tradição evangélica-luterana e os católicos.

\section{A) Imigrantes alemães de confissão evangélica} luterana

Para a Igreja Evangélica Luterana, a escola era uma instância fundamental para a ação eclesial. Entendia-se a leitura da Bíblia como elemento essencial para a vida da fé. No entanto, para Lutero, a escola não teria que ser necessariamente uma atribuição da Igreja. Recomendou ao poder público que abrisse escolas. Em contexto posterior, quando o Estado foi assumindo a função da escola e quando, a partir da influência do Iluminismo, vinculou-se a escola pública com a laicidade, houve uma tendência a favor da escola confessional em diversas regiões de língua alemã (Joerg, 1960). Os imigrantes luteranos no Brasil, além de não terem escolas públicas disponíveis, também vieram com esta influência do Movimento da Restauração. Por isto deram muita atenção ao processo escolar confessional. Em todos os relatórios dos Concílios Gerais do Sínodo Rio-Grandense, o tema escola aparece com ênfase. E a evolução das comunidades protestantes luteranas demonstra o quanto a Igreja assumiu a coordenação no processo de difusão das escolas comunitárias (Hoppen, 1986; Dreher, 1984 e 1986). Entre os imigrantes alemães, o número de escolas comunitárias luteranas foi superior ao das católicas.

\section{B) Imigrantes alemães católicos}

O Projeto de Restauração Religiosa, a partir de 1864 , teve fortes repercussões entre os imigrantes católicos no Brasil. Vários fatores concorreram para que esta ação tomasse as reais proporções que adquiriu. Podemse realçar especialmente:

a)a presença dos imigrantes no Brasil, o que motivou as ordens religiosas dos respectivos países a assistirem a seus emigrados;

b) os problemas entre Estado e Igreja em países europeus (Kulturkampf, perda dos Estados Pontifícios, disputa sobre o direito à educação e outros), levando muitas congregações e ordens religiosas a procurarem países com melhores condições de expansão;

c) a expulsão de ordens e congregações de alguns países europeus, motivando a vinda de religiosos/as de grande liderança, sendo-lhes confiada especialmente a pastoral junto aos imigrantes. Todo um conjunto de congregações masculinas e femininas, vindas no período e marcadas pelas fortes tensões entre Igreja e Estado, dedicou-se ao projeto de Restauração (Romanização) da Igreja no Brasil. ${ }^{8}$

Este clero e estes religiosos e religiosas inspiravamse no princípio de que era preciso integrar a vida social, cultural e econômica numa perspectiva de primazia do espiritual. A ação da Igreja Católica junto aos imigrantes apoiou-se especialmente em três núcleos de ação: acentuada difusão da imprensa, ampla rede de organizações e associações religiosas e culturais e, principalmente, escola e professor. Através destes meios, dinamizavam-se diversos tipos de associações de modo tal que se chegou a uma reafirmação e desenvolvimento da prática religiosa. Além de paróquias que deveriam funcionar de modo mais eficiente, dever-se-ia animar também a ação pastoral através da imprensa, sindicatos, organizações patronais, hospitais, cooperativas, partido político (católico) e, especialmente, organização de escolas e formação de professores (Rabuske, 1974, p. 31).

Num primeiro momento, o afluxo de religiosos europeus foi elevado. Todas as congregações religiosas investiram fortemente nas casas de formação para renovar seus quadros. Muitos egressos destas casas de formação, não tendo optado pela vida religiosa, tornavamse professores comunitários. A partir de 1920, as regiões de imigração, especialmente italiana, alemã e polonesa, haviam se tornado um verdadeiro celeiro de vocações religiosas e de formação de quadros para atuarem nas instâncias de apoio à pastoral católica. É nesse contexto

${ }^{8}$ Para exemplificar, tomemos o caso do Rio Grande do Sul. De 1870 a 1904 chegaram ao estado os Jesuítas, os Franciscanos e as Franciscanas da Caridade, os Palotinos alemães, os Capuchinhos franceses, as Irmãs de São José de Moutiers, os Maristas franceses, as Irmãs de Santa Catarina, os Lassalistas franceses, os Salesianos da Itália e mais de uma centena de padres diocesanos. 
que se entende uma série de iniciativas em relação à escola e ao professor entre imigrantes católicos.

A quarta Assembléia Geral de Católicos da imigração alemã concluiu que família e escola deveriam sempre atuar unidas sob a orientação da Igreja, pois, "para se alcançar os fins religiosos é fundamental que se conserve e se promova a escola paroquial" (DV, 8/ fev./1901). Nesta perspectiva, configurou-se o professor como elemento estratégico de ação, como agente de ligação entre o clero e a comunidade de imigrantes. Schupp (1974), Lutterbeck (1977), Amstad (1924), Rambo (1956) e Rabuske (1974) salientam o quanto algumas ordens e congregações religiosas investiram neste projeto de ação pastoral, no qual a escola e o professor eram instâncias prioritárias. Pretendia-se a escola e o professor caracterizados como paroquiais, em função de um projeto religioso.

A Igreja promovia assembléias de imigrantes católicos alemães para planejar as melhores condições de desenvolvimento da escola comunitária. A partir de 1900 já se formara o consenso de que cada núcleo colonial deveria acolher o professor com casa, roça e benfeitorias. Mas também dispunha do direito de dispensá-lo, caso não correspondesse às expectativas. Além da vinculação com a comunidade, o professor tinha também uma orientação e dependência da autoridade eclesiástica. Ele era considerado uma extensão do padre e, na ausência deste, presidia o culto, acompanhava os doentes com preces, era catequista e animador do canto litúrgico. Enfatizava-se muito que a função do professor era uma vocação, um sacerdócio. Segundo depoimento de um grupo de ex-professores na imigração alemã, foi Alberto Etges $^{9}$ quem melhor sintetizou a descrição do sentido e das funções do professor comunitário. Afirma Etges:

Por todo o tempo que existiu o professor paroquial, foi ele quase sem exceção, uma figura exponencial em numerosas comunidades de nossa diocese. Era um homem polivalente e preparado para o seu mister: professor e educador, catequista, diretor do culto dominical, regente do coral e organista,

${ }^{9}$ Bispo da diocese de Santa Cruz do Sul, RS. Quando começou seu episcopado, na década de 1950, encontrou ainda toda uma dinâmica associativa, escolar, proveniente das iniciativas comunitárias dos imigrantes, anterior à Nacionalização. orientador e animador da comunidade, conselheiro do povo, colaborador do clero, pessoa de confiança das autoridades e outras pessoas de responsabilidade, representante e promotor das entidades sócio-culturais de inspiração católica de então (União Popular, cooperativas, caixas rurais, congressos católi$\cos . .$.$) , correspondente, articulista dos jornais e revistas.$

Era sem dúvida a pessoa mais habilitada do lugar e reconhecido como tal. Sobretudo era um homem de fé, um homem de igreja, com profunda vivência cristã, geralmente pobre e desprendido, despretensioso, reto, idealista e eqüidistante de quaisquer facções partidárias. Era o líder inconteste da comunidade. Nele se concentrava a vida cultural, religiosa e associativa da época. Se então houvera ministérios ordenados, sem dúvida nenhuma teriam sido os diáconos permanentes preconizados pelo Concílio. Por tudo isto, eram figuras imprescindíveis no lugar. Tanto isto era assim que, já não existindo, até hoje não se conseguiu encher convenientemente o vácuo que deixaram, com não pequeno detrimento da vida comunitária. (Etges, 1977, p. 1)

A descrição sintetiza bem o significado e a função do professor enquanto agente e líder de comunidade rural, vinculado a uma atmosfera de "primazia do espiritual”. No projeto de Restauração Religiosa, o professor foi figura estratégica e guardião de uma ordem em que o sistema de referência era o sagrado, em que a organização social estava alicerçada na homogeneidade de pequenos proprietários rurais.

Sem estas referências históricas é difícil entender o amplo processo de escolas comunitárias, vinculadas diretamente à Igreja, com toda uma ampla estrutura de apoio para sua organização e funcionamento. Certamente nem todos os imigrantes vieram com esta perspectiva. Mas a liderança religiosa, coordenadora de toda esta dinâmica, tomava o Movimento da Restauração como referência para desencadear ampla frente de oposição ao ideário liberal.

\section{C) Imigrantes poloneses}

Os imigrantes poloneses também organizaram seu processo escolar étnico, sendo a coordenação desta dinâmica realizada em grande parte por uma vinculação estreita com a Igreja. Esta liderança religiosa foi exercida, no espírito da Restauração, pelos padres missionários da Congregação de São Vicente de Paulo, jun- 
tamente com duas congregações femininas, as Irmãs da Sagrada Família e as Irmãs de Caridade de São Vicente de Paulo, todas oriundas da Polônia. Todavia, os imigrantes poloneses também tiveram seus "Brummer", intelectuais de formação anticlerical e de ideologia socialista, que eram conhecidos como o grupo "progressista". De acordo com Wachowicz, a formação destas duas correntes nada mais era do que a extensão, para o Brasil, da situação predominante na Europa na segunda metade do século XIX, e com uma grande influência na dinâmica comunitária dos imigrantes poloneses.

O surgimento desses novos elementos na vida da colô-

nia polonesa no Brasil causara grande impacto, reanimando suas instituições sociais, já em fase de tomada de consciência coletiva [...] Em 1899, surgiu a primeira tentativa no sentido de organizar e centralizar toda a enorme força social, composta de dezenas de escolas-sociedade, espalhadas pelo Sul do Brasil. (Wachowicz, 1970, p. 27-28).

Também em outros setores que não o escolar ocorreram tentativas no sentido de formar associações, como, por exemplo, "círculos agrícolas", "sindicato dos agricultores", "organização feminina" e outras. No entanto, segundo Wachowicz, houve muita dificuldade na organização concreta deste associativismo, devido aos conflitos ideológicos na liderança.

No âmbito escolar, esta divisão refletiu-se na formação de duas associações que congregavam os professores e animavam o processo escolar entre os imigrantes poloneses. Após as tentativas fracassadas de formar uma única associação, foram fundadas a União dos Professores das Escolas Polonesas Particulares no Brasil, sob a liderança de leigos, e a União de Escolas Polonesas, sob a liderança dos religiosos. As duas sociedades estimularam o processo escolar entre imigrantes poloneses através de cursos para professores, material didático, bibliotecas escolares, bibliotecas volantes, escolas noturnas.

Em 1930, o consulado polonês em Curitiba criou a União Central Polonesa para ser a entidade que, visando superar as divergências constantes entre as duas associações, centralizasse todas as organizações polonesas, não somente as do Paraná. Através desta União Central Polonesa, o governo da Polônia dava algum sub- sídio para as escolas e professores que tivessem o ensino do polonês no currículo. Esta subvenção não era muito significativa para a manutenção das escolas polonesas no Brasil. Perfazia em torno de $11 \%$ do custo destas escolas no Paraná, $12 \%$ no Rio Grande do Sul e $12,45 \%$ em Santa Catarina. Nestes dois últimos estados, houve também um subsídio de aproximadamente $30 \%$ das despesas com a escola por parte do governo municipal. No Paraná o governo estadual assumiu o subsídio (Wachowicz, 1970).

O que chama a atenção nas escolas da imigração polonesa é o número elevado de professoras, especialmente no Paraná. Dos 190 componentes do magistério das escolas étnicas polonesas neste estado, em 1937, 120 eram professoras. Isto se deve em grande parte ao fato de haver um número elevado de escolas atendidas por freiras (idem, p. 34).

\section{D) Imigrantes italianos}

Em relação às escolas dos imigrantes italianos também houve especificidades étnico-culturais. Segundo Moretto Ribeiro (1990, p. 555), não se pode falar genericamente de "escolas da imigração italiana", pois havia escolas particulares italianas, escolas italianas apoiadas pelo governo italiano e escolas paroquiais italianas. Referindo-se às escolas em zona rural do Rio Grande do Sul, diz que estas foram particulares. Foram abertas em lugares mais isolados, onde não havia escola pública, e não tinham vínculo nem com associações italianas nem com o governo italiano. Nos primeiros anos funcionavam na casa do professor, depois passou a haver uma participação maior da comunidade através da construção de instalações escolares e do pagamento do professor. No entanto, não se tinha entre os imigrantes italianos a perspectiva de enfatizar escolas étnicas. Eles faziam insistentes pedidos ao governo em favor de escolas públicas para que os alunos aprendessem o português, para que tivessem uma adaptação mais rápida, possibilitando melhores relações sociais e comerciais com o novo contexto.

As comunidades rurais aceitam a escola particular italiana, mas não como uma situação definitiva. Sistematicamente tomam a iniciativa de apelar para o poder público a fim de 
que participe na manutenção da escola e, principalmente, assuma o pagamento do professor. (Moretto Ribeiro, 1990, p. 557)

Petrone (1990) e Trento (1988) também dizem que as escolas italianas eram efêmeras, não tinham uma estrutura de apoio que lhes desse estabilidade.

A esmagadora maioria destas escolas teve vida efêmera.

Durante algumas décadas, em particular até a Grande Guerra de 1914, aparentemente o quadro escolar mantinha-se relativamente estável. Trata-se, entretanto, de uma estabilidade ilusória, dado que ao mesmo tempo em que surgiram novas escolas, ao sabor de iniciativas individuais, outras tantas fechavam suas portas. Verificava-se, portanto, uma constante substituição parcial dos estabelecimentos, fato na verdade revelador da relativa fragilidade das condições que permitiam sua existência. (Petrone, 1990, p. 611)

Dal Moro (1987) entende que entre os primeiros imigrantes italianos a "gênese da escola teve como base mais sólida o empenho dos colonos em preservar seu patrimônio cultural", e que havia estreita ligação entre igreja e escola. Mas também enfatiza que a escola e o ensino das primeiras letras constituíam-se numa "preocupação menor", pois era em torno da igreja que "gravitava todo o mundo sócio-econômico-cultural dos colonos italianos".

As escolas dos imigrantes italianos em zona rural praticamente não recebiam subvenção do governo italiano, a não ser algum material didático, e “à medida que surgia uma escola pública, a escola particular italiana não se fazia mais necessária" (Moretto Ribeiro, 1990, p. 557; Dal Moro, 1987).

As escolas dos imigrantes italianos apoiadas pelo governo italiano eram aquelas que se localizavam mais em região urbana e nas sedes das colônias. Recebiam apoio financeiro para manter o professor, doação de material escolar, especialmente livros didáticos, e incentivo moral através dos cônsules. O governo italiano também enviava alguns professores. Segundo Moretto Ribeiro (1990) e Petrone (1990), o objetivo do governo italiano era manter o amor pátrio e o espírito de italianidade entre os imigrantes. Em 1905/6 as escolas subsidiadas pelo governo italiano eram 171, com 10.944 alunos. Destas, 53,8\% encontravam-se no Estado de São
Paulo. A partir de 1920, em contexto político de ênfase nacionalista, o governo italiano investiu bastante em material didático padronizado, em perspectiva ideológica fascista, com ênfase no italiano oficial, contra os dialetos (Petrone, 1990, p. 618; Giron, 1998). No entanto, como o interesse dos imigrantes italianos pela escola consistia mais no desejo de aprender o português, não aderiram à articulação de uma estrutura mais ampla de apoio ao processo escolar. Reivindicaram e passaram o mais rapidamente possível para as escolas públicas. A partir de 1915 as escolas italianas foram diminuindo consideravelmente o seu número.

Enquanto na zona rural ocorria a municipalização das escolas italianas, nas sedes municipais cresciam as escolas de religiosos italianos. Em 1921 eram $30 \mathrm{em}$ todo o país, o que significava $15 \%$ do total das escolas de imigrantes italianos. Na década de 1930, aumentaram para $45 \%$ do total, sendo mais freqüentes no Rio Grande do Sul, com 25 escolas religiosas italianas, e em Santa Catarina com 31 (Trento, 1988, p. 183).

Entre as quatro etnias de imigrantes com maior número de escolas, os italianos foram os que menos vinculavam a escola com a dimensão de organização comunitária e cultural. A Igreja era a referência para esta organização e dinâmica coletiva. Giron (1998) diz que, entre italianos na zona rural, a Igreja teve profunda influência, que em nenhuma outra região houve poder maior sobre a vida cultural dos colonos. Ela não era apenas o lugar para o culto, mas o espaço para o qual convergiam as dimensões sociais, culturais e comerciais. Eles não estabeleciam vinculação direta entre a igreja e a escola. Segundo De Boni e Costa (1982, p. 88), em 1924 havia no Rio Grande do Sul 950 igrejas (250 em alvenaria) na região de imigração italiana e somente 57 escolas anexas às igrejas ou capelas. Neste sentido, Dal Moro (1987) diz que, enquanto na década de 1920 havia, no Rio Grande do Sul, 788 escolas da imigração alemã, os 250 mil colonos italianos só tinham 60 escolas particulares. Entendo que, por isto, eles também não tiveram maior problema em reivindicar logo a escola pública. Não há indicação de que tivessem uma estrutura de apoio ao processo escolar com associação de professores, escola normal e produção de material didático. 


\section{E) Imigrantes japoneses}

Os japoneses tinham uma tradição escolar já bem sedimentada ao iniciar a imigração ao Brasil, em 1908 (Saito, 1980). Uma vez em terras brasileiras, em contexto cultural totalmente diferente do de sua tradição, mantiveram nos primeiros anos um ensino mais restrito ao ambiente doméstico. As famílias iniciavam as crianças nos elementos básicos de ler, escrever e contar. Porém, em 1915 já tinham uma organização comunitária de escolas que se expandiu bastante até a nacionalização do ensino, em 1938/9. Segundo depoimento de imigrantes, antes mesmo de providenciar uma sede para suas associações e encontros sociais, uniam-se para a construção da escola e para a manutenção do professor (Vários, 1992, p. 126).

Entre imigrantes japoneses a escola também foi assumida de forma comunitária, mas não sob a liderança e coordenação da Igreja. Schaden (1980) lembra que os japoneses, como xintoístas e budistas, pertenciam a um mundo religioso inteiramente estranho à população nativa. E como a lei lhes negou, por longo tempo, trazerem sacerdotes de sua religião, não desenvolveram suas estruturas comunitárias sob uma liderança religiosa. Organizaram suas escolas sob a coordenação da Associação de Pais, vinculada à Associação de Japoneses ou à respectiva Companhia de Colonização. Das 178 escolas japonesas, em 1932, 141 eram coordenadas pela Associação de Pais (Saito, 1980). Ao visitar as comunidades japonesas no Brasil, Lobo (1932) observou que os pais tinham o máximo empenho em enviar todos os filhos à escola e que a manutenção do professor e da escola era assumida diretamente pelas colônias japonesas e companhias de colonização. Niemeyer afirmou que os imigrantes japoneses "cotizam-se e resolvem construir um prédio para servir de escola para seus filhos aqui nascidos. Esse prédio, oferecem ao Estado e pedem, em seguida, um professor brasileiro" (Niemeyer apud Lobo, 1932, p. 151). No entanto, segundo Saito (1980), Ando (1976) e outros, num turno os alunos freqüentavam a escola para aprenderem as especificidades da cultura japonesa e, no outro turno, com um professor brasileiro, aprendiam os elementos básicos para a adaptação à nova pátria.

Além da organização e manutenção das escolas, também as estradas e outras dimensões necessárias à vida coletiva eram assumidas de forma comunitária pelos imigrantes japoneses (Lobo, 1932).

Estas observações sinalizam uma diferença bastante grande entre as etnias, e mesmo dentro de um mesmo grupo, em relação à dinâmica de seu processo comunitário e sua coordenação.

\section{Estruturasde apoio para o processo escolar entreimigrantes}

As estruturas de apoio para a escola tinham diferenças bastante marcantes entre as etnias, o que certamente se deve a uma conjunção de fatores, como, por exemplo, tradição escolar anterior, instâncias de coordenação, localização em área rural ou urbana, número de imigrantes e outros. Etnias com pequeno número de escolas certamente teriam dificuldade para investir na produção de material didático ou, por exemplo, em instituto de pensão e aposentadoria para seus professores.

Pelas informações disponíveis, sabe-se que entre imigrantes italianos, quando ocorria a conotação comunitária das escolas, isso ocorria em zonas rurais, a partir da liderança religiosa. A comunidade assumia tanto a construção da escola, que, com freqüência, também era capela, como a manutenção do professor. Também se unia para reivindicar material didático junto aos consulados italianos e, principalmente, para pressionar o governo por escolas públicas.

Não se tem notícia de uma Associação de Professores da imigração italiana, de um órgão de divulgação entre os mesmos ou da produção de material didático específico para suas escolas étnicas. Como a escola e a língua italiana não eram consideradas fundamentais para o processo religioso, entende-se que estes imigrantes investiam comunitariamente na escola apenas o estritamente necessário e enquanto não tinham acesso à escola pública. O tipo de escola que mais se desenvolveu e mais tempo perdurou entre imigrantes italianos foi o das escolas particulares, laicas ou de congregações religiosas.

Em relação aos imigrantes japoneses, o processo escolar foi marcantemente comunitário, nas zonas rurais com população predominantemente japonesa. Em cidades, especialmente São Paulo, freqüentavam mais a escola pública. Em 1932, todas as escolas públicas da 
capital tinham alunos de origem japonesa (Demartini, 1998). A especificidade das escolas dos imigrantes japoneses, em relação às outras etnias que investiram nas mesmas, é o fato de que, entre eles, as iniciativas comunitárias não foram coordenadas e dinamizadas pelas igrejas, no Movimento da Restauração. A liderança deste processo era assumida diretamente pelas Associações de Pais, vinculadas à Associação dos Japoneses e/ou à respectiva Companhia de Colonização (Saito, 1980). As Associações de Pais encaminhavam a construção comunitária da escola, a manutenção do professor, a obtenção de material didático do governo japonês e a reivindicação, junto ao governo do estado, de um professor que ensinasse o português no segundo turno escolar. Gradativamente obtiveram do governo também o pagamento dos professores. Não há notícia a respeito de uma Associação de Professores Japoneses no Brasil, nem de um jornal do professor ou de semanas de estudo ou cursos de aperfeiçoamento específicos para estes professores. Os imigrantes japoneses veiculavam as informações e orientações relativas ao processo escolar através de seus jornais.

Divididos entre uma liderança laica e outra religio$\mathrm{sa}$, fortemente dissidente, os poloneses tiveram dificuldade para ações conjuntas nas primeiras décadas de imigração. Isto se refletiu no processo escolar. Somente a partir de 1914 chegaram a alguma forma inicial de associação (Wachowicz, 1970, p. 28), com iniciativas bastante marcantes para montar uma estrutura de apoio ao processo escolar. Construíram comunitariamente as escolas. Assumiram o pagamento dos professores. Criaram as duas associações de professores e também organizaram duas escolas de formação de professores e de lideranças, uma em General Mallet, PR, e outra em Guarani das Missões, RS. Providenciaram semanas de estudo e de atualização pedagógica dos professores. Fizeram gestões junto ao governo polonês para a obtenção de boa parte do material didático; elaboraram e imprimiram também alguns manuais escolares específicos para suas escolas.

A sociedade escolar estabelecia uma taxa para o salário do professor, que, por vezes, era quitada através do valor equivalente em produtos agrícolas. Além de manter duas escolas de preparação de lideranças e pro- fessores, os imigrantes poloneses assumiram coletivamente as despesas de hospedagem e manutenção de seus professores em curso intensivo de um ano, oferecido pelo governo do Estado do Paraná, para habilitá-los a adequarem o programa de ensino das escolas étnicas ao programa oficial, ministrando as aulas em português. O Código de Ensino de 1917 e a Lei Estadual 2.157 de 1922 estabeleciam que todo o ensino nas escolas da imigração fosse em vernáculo, com exceção do ensino de língua estrangeira, adotando-se os programas oficiais de ensino e sujeitando-se à inspeção escolar. Além do preparo intensivo dos professores também foi necessário investir no material didático para atender à exigência legal (Wachowicz, 1970).

Os imigrantes poloneses também elaboraram alguns manuais escolares específicos para suas escolas. O primeiro foi o Manual para as escolas polonesas no Brasil, de Jerônimo Durski, em 1893. A primeira parte do manual é uma cartilha de alfabetização em polonês, no método silábico. A segunda parte é bilíngüe, no método fonético. Ainda tinha um pequeno catecismo em anexo (Wachowicz, 1970, p. 23-24). Antes disto usavam livros didáticos importados da Polônia, além de cartilhas em português. Em 1913, Francisco Hanas editou O Programa do Colégio Polonês Nicolau Copérnico, em Marechal Mallet, muito usado em outras escolas (Gardolinski, 1977). O mesmo autor publicou três manuais de ensino de matemática. Em 1926, Konstanty Lech publicou Normas prático-metodológicas para as escolas polonesas no Brasil. Tratava-se de um manual que, na primeira parte, apresentava fundamentação didáticopsicológica para uso do professor, e na segunda parte, era livro didático para alunos. Também foi autor da Cartilha para as crianças polonesas no Brasil, segundo o método analítico e segundo o método de palavração recomendado e usado nas escolas da imigração polonesa (Wachowicz, 1970, p. 83).

Outra iniciativa para suprir deficiências no trabalho escolar foi a criação de "bibliotecas volantes". Em 1924 circulavam 18 bibliotecas volantes entre os imigrantes poloneses. Também instituíram a figura do "professor volante", que organizava preleções acompanhadas de slides e projetava filmes sobre diversos aspectos do conhecimento significativo para os imigrantes. Apre- 
sentava-os para adultos e crianças. Além disto, ainda foi muito significativa a abertura de um internato para jovens, em Curitiba, permitindo que filhos de imigrantes do interior, almejando continuar os estudos, tivessem oportunidade para isto. A Congregação dos Padres da Missão administrava este internato com o apoio das comunidades.

Estas referências, embora breves, permitem perceber que os poloneses, apesar de serem um grupo de imigrantes numericamente pequeno, investiram significativamente numa estrutura de apoio para sua escola étnica.

Para os imigrantes alemães a escola foi considerada uma instância a merecer atenção especial. A partir de 1870 deixou de ser restrita ao interesse de cada núcleo rural. Começou a ser planejada, incentivada e coordenada pelas Igrejas Católica e Evangélica, adquirindo uma conotação crescentemente confessional. Por isto as confissões religiosas criaram vigorosa estrutura de apoio ao processo escolar, na qual se pode salientar especialmente:

1. Associação de Professores Teuto-Brasileiros Católicos no RS (Deutsch-Katholischer Lehrerverein), em 1898.

2. Associação de Professores Teuto-Brasileiros Evangélicos (Deutsch-Evangelischer Lehrerverein), em 1901.

3. Associação de Professores Teuto-Brasileiros de Santa Catarina (Deutsch-Brasilianischer Lehrerverein in Santa Catarina).

4. Jornal/Revista dos Professores Teuto-Brasileiros Católicos no RS (Mitteilungen, depois Lehrerzeitung), de 1900-1939.

5. Jornal/Revista dos Professores Teuto-Brasileiros Evangélicos no RS (Allgemeine Lehrerzeitung), de 1902-1939.

6. Jornal/Revista dos Professores Teuto-Brasileiros de Santa Catarina (Lehrerzeitung).

7. Escola Normal ou Instituto de Formação para os Professores (Lehrerseminar).

Havia três, de acordo com as confissões religiosas:

a) a do Sínodo Evangélico Luterano Alemão de Missouri,

Ohio e outros estados, fundada em Bom Jesus, perto de São Lourenço, em 1903;

b) a do Sínodo Rio-Grandense, fundada em 1909. Funcionou no Asilo Betânia, Taquari, até 1910, quando foi transferida para Santa Cruz. Em 1926, foi transferida para São Leopoldo; c) a dos Católicos, fundada em 1902 em Bom Princípio, ficando a cargo dos Irmãos Maristas. Não vingou por falta de candidatos. Em 1923, reiniciou em Arroio do Meio, e, em 1930, foi transferida para Novo Hamburgo.

8. O Fundo de Pensão e Aposentadoria (RHGK = Ruhe und Hinterbliebene Gehaltskasse) comum aos professores teutobrasileiros de ambas as confissões religiosas e dos diversos estados com imigrantes alemães no Brasil.

9. Realização de Assembléias Escolares (Deutschbrasilianische Schultage), que eram interconfessionais.

10. Assembléias Regionais e Locais de Professores Teuto-Brasileiros (Lehrerkonferenzen mit Lehrproben).

11. Cursos e Semanas de Estudo, que eram regionais.

12. Ampla produção e difusão de material didático específico para a escola teuto-brasileira e adequado a seus objetivos. Foram produzidos acima de 150 manuais didáticos para uso na escola teuto-brasileira.

A primeira iniciativa quanto à estrutura de apoio ao processo escolar foi a criação da Associação de Professores, tanto entre imigrantes alemães católicos quanto evangélicos. Ela serviria como instância de referência para as atividades e necessidades dos docentes e, principalmente, como canal de união entre igreja e escola. A Associação dos Professores Teuto-Brasileiros Católicos foi criada no Primeiro Congresso de Católicos no Rio Grande do Sul, o que traduz sua vinculação direta com a Igreja. Também a Associação de Professores Teuto-Brasileiros Evangélicos foi criada através do Sínodo Rio-Grandense.

A imprensa e os três jornais/revistas criados em função da escola teuto-brasileira têm um significado especial entre as estruturas de apoio ao processo escolar. Ao se percorrer jornais e revistas editados pelos e para os teuto-brasileiros, tem-se noção de quanto a questão escolar era constantemente tratada como tema de interesse comum. Em 1938 circulavam entre os imigrantes alemães 37 títulos diferentes de jornais, revistas mensais, folhas semanais e anuários. Entre estes, três eram jornais/revistas que tratavam especificamente da questão escolar, a saber, o Jornal do Professor Teuto-Brasileiro Católico, o Jornal do Professor Teuto-Brasileiro Evangélico e a revista $O$ Livro Escolar (Das Schulbuch). $\mathrm{O}$ conjunto destes três jornais/revistas é uma fonte 
riquíssima de pesquisa. Apresento algumas referências em relação a cada um destes periódicos:

\section{Lehrerzeitung. Vereinsblatt des deutschen} katholischen Lehrervereins in Rio Grande do Sul. (Nos primeiros sete anos o título foi: Mitteilungen des katholischen Lehrer- und Erziehungsvereins in Rio Grande do Sul).

Foi o jornal da Associação de Professores TeutoBrasileiros Católicos do Rio Grande do Sul. Iniciou em janeiro de 1900 e foi extinto pelo processo de nacionalização do ensino, em setembro de 1939. Impresso em alemão, normalmente em letra gótica. Sua edição foi suspensa por dois anos e dois meses, de novembro de 1917 a janeiro de 1920, em conseqüência da Primeira Guerra Mundial. A coleção existe quase completa, somando-se os números existentes no Instituto Anchietano de Pesquisas, de São Leopoldo, com os do Instituto Hans Staden, de São Paulo. Falta localizar os números correspondentes a janeiro de 1907, abril de 1922, janeiro de 1924 e agosto de 1924.

A Associação de Professores Teuto-Brasileiros Católicos (Lehrerverein), fundada em 1898, já em 1900 assumiu a edição do jornal/revista da associação. Os objetivos do jornal foram expostos no editorial do primeiro número, assinado pelo Presidente da Associação, professor Siegfried Kniest, então professor em São João do Montenegro. Basicamente tratava-se de promover a escola comunitária (paroquial) de acordo com a perspectiva católica, promover a formação dos professores, seu acompanhamento e apoio tanto na prática do magistério quanto nas demais instâncias relacionadas com a função. Apontava também um leque de objetivos específicos para serem trabalhados através do jornal: obrigatoriedade escolar mínima de quatro anos, currículo mínimo comum para todas as escolas, impressão e difusão de material didático. Enfim, o objetivo era ter um jornal para a promoção da escola e do professor na perspectiva católica.

2. Allgemeine Lehrerzeitung für Rio Grande do Sul. Vereinsblatt des deutschen evangelischen Lehrervereins in Rio Grande do Sul. Foi o jornal da Associação de Professores Teuto-Brasileiros Evangéli- cos do Rio Grande do Sul, publicado de 1901 até outubro de 1939. Os objetivos da Allgemeine Lehrerzeitung são semelhantes, na perspectiva evangélica, a seu congênere católico, já exposto acima. Este é o periódico do qual falta ainda encontrar em torno de 1/3 dos números. Até 1909 foram encontrados pouquíssimos números. A maior parte dos números localizados até o momento está no Instituto Hans Staden, SP.

3. Das Schulbuch. Organ zum Ausbau der Schulbuchliteratur in Brasilien. Editado por Rotermund, São Leopoldo, de 1917 a 1938. Foi concebido como veículo para o fomento e a elaboração do livro didático.

Aparecem em destaque, no frontispício, junto ao título, e em todos os números editados, três informações:

A redação está nas mãos de pedagogos renomados; todas as colaborações devem ser enviadas à Editora Rotermund e Cia., São Leopoldo.

Será enviado, gratuitamente, a todos os professores e interessados.

Editado segundo a necessidade, tratando dos diversos aspectos que envolvem o trabalho pedagógico. Aceita-se, gratuitamente, o anúncio de procura e de oferta de vaga para professor.

Os três primeiros números foram publicados respectivamente em julho, agosto e setembro de 1917. Sobre os números 4 e 5 ainda não há informações. Houve interrupção de sete anos na publicação, reaparecendo com o número 6 em outubro de 1925 . Até 1938 foram publicados 52 números, dos quais 50 estão preservados na Editora Rotermund, em São Leopoldo.

Estes três periódicos acima são de suma importância para pesquisar a questão escolar entre teuto-brasileiros. Neles se encontram o contexto e o conjunto de notícias relativas à organização escolar entre imigrantes alemães. As duas coleções mais completas são a Lehrerzeitung e o Das Schulbuch. A coleção que possui mais lacunas até o momento é a Allgemeine Lehrerzeitung. Talvez esteja perdida como coleção. No período da nacionalização do ensino foi destruída grande parte do material didático encontrado pelos agentes da nacionalização. Os imigrantes também colaboraram 
neste processo, para se preservarem. O desafio está posto para um trabalho coletivo no sentido de tentar a recuperação mais completa possível destas três coleções.

Tanto imigrantes alemães católicos quanto evangélicos também tiveram sua escola normal, centro de formação de professores e de discussão pedagógica. Entre os católicos, sempre foi elevado o número de professores sem titulação na escola normal. Geralmente eram os egressos de seminários ou juvenatos de religiosos que adquiriam a formação pedagógica através de um estágio junto a um professor experiente. Ainda chama a atenção a existência de toda uma dinâmica de formação/atualização dos professores em serviço. Promoviam-se sistematicamente reuniões locais e regionais de professores. Na primeira parte do encontro havia a reflexão teórica sobre método e a troca de idéias sobre manuais didáticos. Na segunda, partia-se para as aulas demonstrativas junto aos alunos da localidade em que se realizava a reunião.

Outra iniciativa marcante na estrutura de apoio ao processo escolar da imigração alemã foi a produção de material didático específico para este processo escolar. Até o momento já foram encontrados 138 títulos de manuais produzidos especificamente para a escola teutobrasileira. Nos periódicos teuto-brasileiros há referência a mais duas dezenas de manuais, no entanto, ainda não localizados. A citação completa de todos os periódicos e manuais didáticos encontrados até 1994, com informações sobre acervo(s) no qual se encontram, bem como sobre seu estado de conservação, encontra-se em Kreutz (1994a).

As associações de professores teuto-brasileiros também criaram de forma interconfessional e em nível interestadual um fundo de pensão e aposentadoria, realizaram congressos e criaram a Associação Brasileira de Professores da Imigração Alemã.

Toda esta ampla estrutura de apoio para o processo escolar teuto-brasileiro teve seu maior centro de concepção, animação e produção no Rio Grande do Sul. Neste estado estavam localizadas 1.041 das 1.579 escolas teuto-brasileiras, em 1937. Santa Catarina, que tinha 361 escolas da imigração alemã, também possuía uma associação de professores, um jornal do professor e editou alguns manuais didáticos. Não tenho ciência de um levantamento sistematizado desta produção. O material didático editado no Brasil também foi usado em escolas da imigração alemã da Argentina, do Uruguai e do Paraguai.

É notável como os imigrantes, especialmente os poloneses, japoneses e alemães, criaram uma ampla estrutura de apoio para suas escolas étnicas.

\section{Conclusões?}

Este texto foi elaborado com o propósito de fazer uma primeira aproximação à temática das instâncias de coordenação e das estruturas de apoio nas escolas comunitárias dos imigrantes. Ciente de uma certa provisoriedade em relação ao conhecimento do conjunto das pesquisas que estão sendo realizadas sobre as escolas da imigração, e ciente também de fortes discrepâncias em relação a dados numéricos, apresento este texto na perspectiva de provocar mais estudos, debates e, certamente, complementação/reinterpretação de informações. Grande parte das fontes é do momento tenso da nacionalização compulsória do ensino e/ou das disputas de espaço entre igrejas e o ideário liberal, e, por isto, elas refletem fortemente o lugar social, cultural e ideológico-político a partir do qual foram elaboradas.

Percebo que, ao tratar das escolas étnicas dos imigrantes no Brasil, é necessário fazer distinção entre escolas comunitárias, escolas particulares de congregações religiosas, escolas particulares laicas urbanas e também escolas particulares em área rural, especialmente nos primeiros tempos da imigração. Constato também que o processo escolar comunitário começou a ser estruturado mais a partir do final do século XIX, sendo em grande parte fruto das tensões entre igrejas e lideranças laicas sob o ideário liberal. Neste contexto de disputa por espaço, as igrejas de confissão católica e luterana começaram a marcar presença muito forte entre imigrantes, fomentando a criação de todo um conjunto de estruturas de apoio a seu projeto, especialmente ampla difusão da imprensa étnico-religiosa, variadas formas de associativismo e uma bem estruturada rede de escolas. Percebe-se claramente nesta dinâmica toda a tensão entre ideário liberal e restauração religiosa, especialmente por parte da Igreja Católica, que foi recebendo expres- 
sivo número de religiosos e religiosas provenientes diretamente desta tensão ideológica na Europa. Em área urbana também houve casos, embora menos numerosos, no entanto muito influentes, de liderança laica, na perspectiva do ideário liberal. Entre os imigrantes japoneses com tradição religiosa do xintoísmo e do budismo, proibidos de trazerem seus sacerdotes, a liderança da dinâmica comunitária e da promoção das escolas foi predominantemente laica.

Percebo igualmente que as escolas comunitárias tiveram especificidades de acordo com as etnias. O processo identitário dos diferentes grupos étnicos concorreu e interferiu na forma como estruturavam sua vida coletiva. Estudos históricos da educação na perspectiva cultural contribuirão para a compreensão do processo escolar comunitário dos imigrantes.

A ampla estrutura de apoio criada para fundamentar o processo escolar dos imigrantes no Brasil é pouco conhecida, e motiva todo um leque de pesquisas. Refiro-me especialmente à produção de material didático próprio, elaborado para as escolas étnicas no Brasil, entendendo-se que não se deveria importá-lo da terra de origem por não atender à dinâmica da vida e dos desafios na nova pátria. Mas refiro-me também às coleções dos jornais/revistas do professor, à revista $O$ Livro Escolar (Das Schulbuch), à imprensa étnica em geral, tratando continuamente das questões da escola. Enfim, todas as iniciativas relacionadas com a escola e a forma como estavam compondo com outras associações, criando um ambiente cultural em que a escolarização era considerada algo inerente a toda a dinâmica coletiva, são temas para pesquisa. $\mathrm{O}$ processo escolar comunitário de grupos de imigrantes é pouco conhecido em nossa história da educação; no entanto, parece-me que foi uma iniciativa singular e marcante para o contex to histórico de então. Acima de dois mil núcleos de imigrantes mantinham, especialmente nas décadas de 1920/30, um processo escolar comunitário no qual havia a integração da quase totalidade das crianças em idade escolar. Esta temática certamente demanda ainda muitas pesquisas.

LÚCIO KREUTZ é professor no Programa de Pós-Graduação em Educação da Universidade do Vale do Rio dos Sinos (UNISINOS), em São Leopoldo-RS e pesquisador do CNPq. Vem desenvolvendo pesquisas relacionadas com o processo escolar étnico entre imigrantes no Brasil, com ênfase no processo escolar entre imigrantes alemães. Sobre esta temática versam suas principais publicações, algumas citadas nas referências bibliográficas do presente texto. Nos últimos anos também vem desenvolvendo estudos comparativos sobre alguns aspectos do processo escolar entre as diversas etnias de imigrantes no Brasil.

E-mail: lucio@netu.unisinos.br

\section{Referências Bibliográficas}

AMSTAD, Theodor, (1924). Hundert Jahre Deutschtum in Rio Grande do Sul, 1824-1924. Porto Alegre: Typhographia do Centro.

ANDO, Zempati, (1976). Estudos sócio-históricos da imigração japonesa. São Paulo: Centro de Estudos Nipo-Brasileiros.

BRUIT, Hector, (1982). Acumulação capitalista na América Latina. São Paulo: Brasiliense.

CARNEIRO, José Fernando, (1950). Imigração e colonização no Brasil. Rio de Janeiro: Universidade do Brasil.

, (1960). O Império e a colonização no sul do Brasil. In:

Fundamentos da cultura riograndense. Porto Alegre, Faculdade de Filosofia, Universidade Federal do Rio Grande do Sul.

CORDEIRO DE FARIAS, Oswaldo, (1942a). Nacionalização. Porto Alegre: Livraria Globo.

, (1942b). Relatório apresentado ao Presidente da República. In: SILVA, M. C. et al. (orgs.). Rio Grande do Sul: viagem da terra gaúcha. Porto Alegre: Cosmos.

COSTA, M. E. Viotti, (1977). Da Monarquia à República: momentos decisivos. São Paulo: Grijalbo.

DALBEY, Richard O., (1969). The german private schools of southern Brazil during the Vargas years, 1930-1945: German nationalism vs. Brazilian nationalization. Indiana University, USA.

DAL MORO, Selina M. (1987). Escola, Igreja e Estado nas colônias italianas. Educação e Realidade, v. 12, nº 2, p. 57-79.

DE BONI, Luis A., (1980). O catolicismo da imigração: do triunfo à crise. In: RS: imigração x colonização. Porto Alegre: Mercado Aberto. , (1987). Presença italiana no Brasil. Porto Alegre: EST.

DE BONI, Luis A. \& COSTA, R. (1982). Os italianos do Rio Grande do Sul. $2^{\mathrm{a}}$ ed. Porto Alegre: EST/UCS/VOZES.

DEMARTINI, Zeila de B. F., (1998). A educação entre famílias de imigrantes japoneses: elementos para a história da educação 
brasileira. Texto apresentado no IV Congreso Ibero-Americano de Historia de la Educación Latinoamericana. Santiago, Chile.

DEMARTINI, Zeila de B. F., ESPOSITO, Yara Lúcia, (1989). São

Paulo no início do século e suas escolas diferenciadas. Ciência e Cultura, São Paulo, v. 41, n. 10, p. 981-995.

DIEGUES JR., Manuel, (1960). Regiões culturais do Brasil. Rio de Janeiro: CBPE, INEP, MEC.

(1976). Etnias e culturas no Brasil. $5^{\mathrm{a}}$ ed. Rio de Janeiro: Civilização Brasileira.

DREHER, Martin N., (1984). Igreja e germanidade. São Leopoldo: Sinodal; Porto Alegre: EST; Caxias do Sul: EDUCS.

(1986). Hermann Borchard em São Leopoldo. Simpósio de História da Igreja. São Leopoldo: Rotermund, p. 23-35.

DS = DIE DEUTSCHE SCHULE IM AUSLANDE, (1933). Monatsschrift fuer deutsche Erziehung in Schule und Familie. XXV Jahrgang. Wolfenbuettel, Heckners Verlag.

DV=DEUTSCHES VOLKSBLATT, (1872-1939). Unabhaengige Zeitung fuer: Wahrheit, Freiheit und Recht. São Leopoldo e Porto Alegre: Typhographia do Centro.

ETGES, Alberto, (1977). O professor paroquial. SKT Paulusblatt. Porto Alegre, Sociedade União Popular (Volksverein), v. 60.

GARDOLINSKI, E., (1977). Escolas da colonização polonesa no Rio Grande do Sul. Caxias do Sul: Universidade de Caxias do Sul e Escola Superior de Teologia São Lourenço de Brindes.

GIRON, Loraine Slomp, (1998). Colônia italiana e educação. História da Educação, v. 2, nº 4, p. 87-106.

HOPPEN, Arnildo, (1986). Fundação do Ginásio Sinodal no contexto do sistema escolar do Sínodo Rio-Grandense. Simpósio de História da Igreja. São Leopoldo: Rotermund, p. 123-145.

JOERG, Hans, (1960). Die Entwicklung des Volkschulwesens im heutigen Kreise Kreuznach bis zum Ende des 18. Jahrhunderts. Duesseldorf, Michael Triltsch Verlag.

KREUTZ, Lúcio, (1991). O professor paroquial: magistério e imigração alemã. Florianópolis/ Porto Alegre/ Caxias do Sul: UFSC/ UFRGS/UCS

(1994a). Material didático e currículo na escola teutobrasileira. São Leopoldo: Editora UNISINOS.

,(1994b). A escola teuto-brasileira católica e a nacionalização do ensino. In: MÜLLER, Telmo Lauro (org.). Nacionalização e imigração alemã. São Leopoldo: Editora UNISINOS. (1994c). Escolas da imigração alemã no Rio Grande do Sul: perspectiva histórica. In: MAUCH, C. \& VASCONCELOS, N. (orgs.). Os alemães no Sul do Brasil : cultura, etnicidade, história. Canoas: Editora ULBRA.

(2000a). A educação de imigrantes no Brasil. In: LOPES, E. M. T., FARIA FILHO, L. M., VEIGA, C. G. (orgs.). 500 anos de educação no Brasil. Belo Horizonte: Autêntica.

, (2000b). Imigração alemã e processo escolar na Argentina, no Brasil e no Chile, de 1824 a 1939. Estudos Leopoldenses Série Educação, São Leopoldo: UNISINOS, v. 4, $\mathrm{n}^{\circ}$ 6, p. 23-36.

LOBO, Bruno, (1932). De japonez a brasileiro. Rio de Janeiro: Typographia do Departamento Nacional de Estatística.

LUTTERBECK, Jorge, (1977). Jesuitas no Sul do Brasil. São Leopoldo: Instituto Anchietano de Pesquisas (Publicações Avulsas, 3).

LZ=LEHRERZEITUNG, (1907-1939). Vereinsblatt des Deutschbrasilianischen Lehrervereins in Rio Grande do Sul. Porto Alegre: Typhographia do Centro.

MARX, Karl, (1981). Formações econômicas pré-capitalistas. $3^{\mathrm{a}} \mathrm{ed}$. Rio de Janeiro: Paz e Terra.

MORETTO RIBEIRO, Liane Beatriz, (1990). Escolas italianas em zona rural do Rio Grande do Sul. In: DE BONI, Luis A. (org.). A presença italiana no Brasil. Porto Alegre; Torino: Escola Superior de Teologia; Fondazione Giovanni Agnelli, v. II.

PETRONE, Pasquale, (1990). Italianos e descendentes do Brasil: escola e língua. In: DE BONI, Luis A. (org.). A presença italiana no Brasil. Porto Alegre; Torino: Escola Superior de Teologia; Fondazione Giovanni Agnelli, v. II.

RABUSKE, Arthur, (1974). Eles se empenharam pelo erguimento do bem-estar material da colônia alemã do Rio Grande do Sul. Anais do $1^{\circ}$ Simpósio de História da Imigração e Colonização Alemã do RS. São Leopoldo, Comissão Organizadora do Simpósio. p. 31-53.

RAMBO, Arthur B., (1994). A escola comunitária teuto-brasileira católica. São Leopoldo: Editora UNISINOS. (1996). A escola comunitária teuto-brasileira católica. A Associação dos Professores e a Escola Normal. São Leopoldo: Editora UNISINOS.

RAMBO, Balduíno, (1956). A imigração alemã. In: Enciclopédia RioGrandense. O Rio Grande Antigo. Canoas: Regional, v. I, p. 77-126. 
ROMANO, Roberto, (1981). Conservadorismo romântico : origem do totalitarismo. São Paulo: Brasiliense.

SAITO, Hiroshi, (1980). A presença japonesa no Brasil. São Paulo: T. A. Queiroz/EDUSP.

SCHADEN, Egon, (1980). Alemães e japoneses: uma visão comparativa. In: SAITO, Hiroshi (org.). A presença japonesa no Brasil. São Paulo: T. A. Queiroz/EDUSP.

SCHMID, Albert, (1949). Die Brummer. Separata do Suplemento A Nação, $\mathrm{n}^{\circ}$ 15683-15690. Porto Alegre: A Nação.

SCHORER PETRONE, Maria Tereza, (1982). O imigrante e a pequena propriedade. São Paulo: Brasiliense.

SCHUPP, Ambros, (1974). Die deutsche Jesuiten-Mission in Rio Grande do Sul. Wiederherstellung und Herausgabe von Pater Arthur Rabuske, SJ. São Leopoldo, UNISINOS.

SOUZA, J. P. Coelho de, (1941). Denúncia : o nazismo nas escolas do Rio Grande do Sul. Porto Alegre: Ed. Thurmann.
TRAVERSINI, Clarice Salete, (1998). Reflexões sobre o sucesso da alfabetização : a escola e o contexto cultural de Poço das Antas RS. Mestrado em Educação. Faculdade de Educação da Universidade Federal do Rio Grande do Sul.

TRENTO, Ângelo (1988). Do outro lado do Atlântico: um século de imigração italiana no Brasil. São Paulo: Nobel; Instituto Cultural Ítalo-Brasileiro. Tradução de Mariarosaria Fabris e Luiz Eduardo de Lima Brandão.

VÁRIOS AUTORES, (1992). Uma epopéia moderna : 80 anos de imigração japonesa no Brasil. São Paulo: Hucitec/Sociedade Brasileira de Cultura Japonesa.

WACHOWICZ, Ruy Cristovam, (1970). As escolas da colonização polonesa no Brasil. In: Anais da comunidade brasileiro-polone$s a$. Curitiba: Superintendência do Centenário da Imigração Polonesa no Paraná, p. 13-110. 